\title{
Assessment of dairy products consumed on the Arakmarket as determined by heavy metal residues
}

\author{
Mohammad Rezaei ${ }^{1}$, Hajar Akbari Dastjerdi ${ }^{2}$, Hassan Jafari ${ }^{3}$, Ali Farahi ${ }^{4}$, Arman Shahabi ${ }^{4}$, \\ Hossein Javdani $^{4}$, Hossein Teimoory ${ }^{5}$, Mohammad Yahyaei $^{6}$, Ali Akbar Malekirad ${ }^{2^{*}}$ \\ ${ }^{1}$ Department of Food Safety and Hygiene, School of Public Health, Tehran University of Medical Sciences (TUMS), Tehran, Iran \\ ${ }^{2}$ Department of Biology, Payame Noor University, Tehran, Iran; ${ }^{*}$ Corresponding Author: Ak_malekirad@yahoo.com \\ ${ }^{3}$ Arak University of Medical Sciences, Arak, Iran \\ ${ }^{4}$ Department of Veterinary, School of Veterinary, Shahid Bahonar University of Kerman, Kerman, Iran \\ ${ }^{5}$ Soren Tech Toos Laboratory, Food \& Biotechnology North East Town, Toos Industrial Town, Mashhad, Iran \\ ${ }^{6}$ Department of New Sciences and Technologies, Life Science Engineering Group, University of Tehran, Tehran, Iran
}

Received 22 December 2013; revised 27 January 2014; accepted 4 February 2014

Copyright (C) 2014 Mohammad Rezaei et al. This is an open access article distributed under the Creative Commons Attribution License, which permits unrestricted use, distribution, and reproduction in any medium, provided the original work is properly cited. In accordance of the Creative Commons Attribution License all Copyrights (C) 2014 are reserved for SCIRP and the owner of the intellectual property Mohammad Rezaei et al. All Copyright (C) 2014 are guarded by law and by SCIRP as a guardian.

\section{ABSTRACT}

Dairy products are nutritious drink and can play a significant part in a healthy diet. The safety of dairy products decreases with increasing concentration of toxic compounds and environmental pollutants (especially heavy metals). In the present study, the contamination of $\mathrm{Al}, \mathrm{Sn}$, $\mathrm{As}, \mathrm{Cd}, \mathrm{Hg}$ and $\mathrm{Pb}$ in dairy products (pasteurized milk, yogurt, yogurt drink, cheese) consumed in Arak, Iran, 2013 was evaluated using inductively coupled plasma mass spectrometry (ICP-SFMS) method. To meet the aim, 60 samples of 5 different brands, consisting of pasteurized milk, yogurt, yogurt drink, cheese $(n=15)$ were selected and analyzed for heavy metals content. $100 \%$ of the samples were positive regarding the total average and range concentration of $\mathrm{Al}, \mathrm{Sn}$, $\mathrm{As}, \mathrm{Cd}, \mathrm{Hg}$ and $\mathrm{Pb}$ in dairy products was $\mathbf{1 6 8 . 2 5}$ \pm 92.2 (30.6 - 356.5), $5.9 \pm 4$ (1.1 - 16), $3.2 \pm 1.95$ (0.4 - 8.1), $4.55 \pm 2.6$ (0.6 - 10.6), $23.15 \pm 10.4$ (6.8 $50.2)$ and $15.4 \pm 8.53(3.1-40.2) \mu \mathrm{g} / \mathrm{kg}$, respectively. $28.3 \%$ (17 of 60 samples) of dairy products samples had lead $(\mathrm{Pb})$ greater than EU limit and national Iranian standard $(20 \mu \mathrm{g} / \mathrm{kg})$. Statistical analysis indicated except about As in pasteurized milk and cheese there was no significant difference between products in terms of heavy metals content.

\section{KEYWORDS}

Heavy Metals; Milk; Cheese; Yogurt; Food

\section{Safety; ICP}

\section{INTRODUCTION}

Milk and milk products are one of the main sources of minerals [1] and rich in calcium, phosphorus, vitamins and proteins [2], also are basic foods in the human diet. As an excretion of the mammary gland, milk can carry numerous xenobiotic substances (pesticides, antibiotics, drugs, heavy metals and various environmental contaminants), which is a risky factor for the health and safety of the consumer and new chemical medicines and antibiotics have negative side effects [3]. Heavy metals are essential for correct body metabolism however the ranges between their effective and toxic levels are small. Heavy metal contamination raises environmental concerns, such as entrance on the food chain, which can be potentially harmful to human's health. Trace elements are shown to have a multitude of toxic effects such as acute syndrome and neurotoxic effects [4,5]. Detection, determination and comparing of heavy metals in dairy products with standard to determine the safety of them have been a subject of numerous studies throughout last decades. Malhat et al. (2012) reported mean levels of 4.404 and $0.288 \mu \mathrm{g} / \mathrm{g}$ for lead and cadmium, respectively, in cow milk collected from different sites in El-Qaliubiya governorate, Egypt [6]. Fatima et al. (2005) reported that the $\mathrm{Pb}$ was determined in two UHT samples with concentration swell below the PTW limit defined by WHO [7]. Studies performed in the various foods in Arak city, showed that this area requires more attention to the foodstuff and regularly monitor pollutants in food [2,8,9]. The aim of 
this study was to determine the contents of $\mathrm{Al}, \mathrm{Sn}$, As, $\mathrm{Cd}, \mathrm{Hg}$ and $\mathrm{Pb}$ in pasteurized milk, yoghurt, yoghurt drink and cheese of five brands available in Iran in the region of Arak 2013.

\section{MATERIALS \& METHODS}

\subsection{Chemicals}

All the reagents and chemicals Merck (Darmstadt, Germany) were used of analytical grade. De-ionized water was used throughout the work. Concentrated nitric acid (65\%), were spectroscopic grades Merck (Darmstadt, Germany).

\subsection{Apparatus}

ICP-OES measurements were performed using an ICP spectrometer working in a simultaneous mode.

\subsection{Sampling and Analysis}

A total of 60 dairy product samples of 5 different brands included of pasteurized milk, yoghurt, yoghurt drink and cheese $(n=15)$ were randomly selected from local supermarket in Arak city, 2013. Samples were conditioned in sterile plastic container and kept at $4^{\circ} \mathrm{C}$ until analyses that were carried out in same day. Statistical analysis with SAS software (9.1) was carried out In order to determine significance difference between product's heavy metal content.

\subsection{Sample Preparation}

Six elements (Al, Sn, As, Cd, Hg and $\mathrm{Pb}$ ) were determined in each dairy product samples. Prior to analysis samples must be decomposed with the appropriate methods procedure with digestcontaining reduced amounts of carbon residues. In order to minimize the effects of the organic matrix, closed vessel acid decomposition in microwave oven system was used. Moreover, it may provide faster, more efficient process and reduce or eliminate the risk of sample contamination and losses of analytes. A microwave assisted-acid digestion procedure was carried out, in order to achieve a shorter digestion time and using minimum amount of acid. Duplicate of $2.0 \mathrm{~mL}$ of each dairy product samples were taken into microwave vessels but well shaken, opened and sampled by pouring directly from the original container into the microwavevessel. Added the samples to each vessels and $10 \mathrm{~mL}$ of a concentrated $\mathrm{HNO}_{3}-\mathrm{H}_{2} \mathrm{O}_{2}(2: 1, \mathrm{v} / \mathrm{v})$ and kept samples for $10 \mathrm{~min}$ at room temperature till the samples were homogenized, and then placed the vessels in covered PTFE container. This was then heated following a one-stage digestion programmed at $80 \%$ of total power (900 W), for 3 - $5 \mathrm{~min}$. After cooling, the resulting solutions were evaporated to semidried mass to remove an excess acid, and then diluted up to $50.0 \mathrm{~mL}$ in volumetric flasks and kept as a stock sample solution $[10,11]$.

\section{RESULTS AND DISCUSSION}

Levels of heavy metal in dairy products are summarized in Table 1. The results from samples showed that the pasteurized milk contained (mean \pm S.D) of Al, Sn, As, $\mathrm{Cd}, \mathrm{Hg}$ and $\mathrm{Pb}, 135 \pm 85.7,4.8 \pm 3.6,2.3 \pm 1.6,3.95$ \pm 2.3 , $21.17 \pm 9.6$ and $12.5 \pm 7.6 \mu \mathrm{g} / \mathrm{l}$, respectively. Yoghurt drink contained of $157.9 \pm 89,5 \pm 3.2,2.9 \pm 1.7,4$ $\pm 2.6,20.3 \pm 8.8$ and $14.3 \pm 7.6 \mu \mathrm{g} / \mathrm{l}$, respectively, yoghurt contained of $186 \pm 79.4,6 \pm 4,3.3 \pm 2$, $4.8 \pm 2.6$, $23.8 \pm 10.9$ and $16.6 \pm 8.9 \mu \mathrm{g} / \mathrm{l}$, respectively and cheese contained of $194.2 \pm 109.2,7.5 \pm 4.7,4.3 \pm 2.1$, $5.4 \pm 2.7$, $27.2 \pm 11.6$ and $18.2 \pm 9.6 \mu \mathrm{g} / \mathrm{kg}$ (Table 1). Accordingly, the highest and least amount of $\mathrm{Pb}$ samples was found in cheese, yoghurt, yoghurt drink and pasteurized milk samples, respectively. Mean and range concentration of $\mathrm{Pb}$ in samples was $18.2 \pm 9.6$ (3.8 - 40.2), $16.6 \pm 8.9$ (3.6 - 35), $14.3 \pm 7.6$ (3.1 - 29) and $12.5 \pm 7.6$ (3.2 - 27.5) $\mu \mathrm{g} / \mathrm{l} \mathrm{or} \mathrm{kg,}$ respectively (Table 1). 28.3\% (17 of 60 samples) of dairy product samples had lead $(\mathrm{Pb})$ greater than EU limit and national Iranian standard $(20 \mu \mathrm{g} / \mathrm{kg})$. The amounts of lead in the samples, pasteurized milk are the best and cheeses have the highest levels of contamination. In the each product manufacturing process, biochemical content and their concentration can influence the metal concentrations. It is well known lead has a high affinity to caseins. In this study cheeses has the highest content of lead that this can be due to the high concentration of casein in it [12]. Except for asin pasteurized milk and cheese there is no significant difference $(p<0.05)$ there was no significant difference between products in terms of heavy metals content (Tables 1 and 2). The results

Table 1. The Comparisons between means of heavy metal content between various dairy products ( $\mu \mathrm{g} / \mathrm{l})$.

\begin{tabular}{|c|c|c|c|c|c|c|}
\hline & As & sn & Al & pb & Hg & Cd \\
\hline Pasteurized Milk & $2.28^{\mathrm{a}}$ & $4.76^{\mathrm{a}}$ & $134.9^{\mathrm{a}}$ & $12.5^{\mathrm{a}}$ & $21.16^{\mathrm{a}}$ & $3.94^{\mathrm{a}}$ \\
\hline Cheese & $4.28^{\mathrm{b}}$ & $7.5^{\mathrm{a}}$ & $194.18^{\mathrm{a}}$ & $18.21^{\mathrm{a}}$ & $27.27^{\mathrm{a}}$ & $5.4^{\mathrm{a}}$ \\
\hline Yogurt & $3.34^{\mathrm{ab}}$ & $6.07^{\mathrm{a}}$ & $186.02^{\mathrm{a}}$ & $16.56^{\mathrm{a}}$ & $23.81^{\mathrm{a}}$ & $4.79^{a}$ \\
\hline Yogurt drink & $2.95^{\mathrm{ab}}$ & $5.09^{\mathrm{a}}$ & $157.88^{\mathrm{a}}$ & $14.34^{\mathrm{a}}$ & $20.35^{\mathrm{a}}$ & $4.06^{\mathrm{a}}$ \\
\hline SD & 0.48 & 1.01 & 23.61 & 2.18 & 2.65 & 0.66 \\
\hline
\end{tabular}




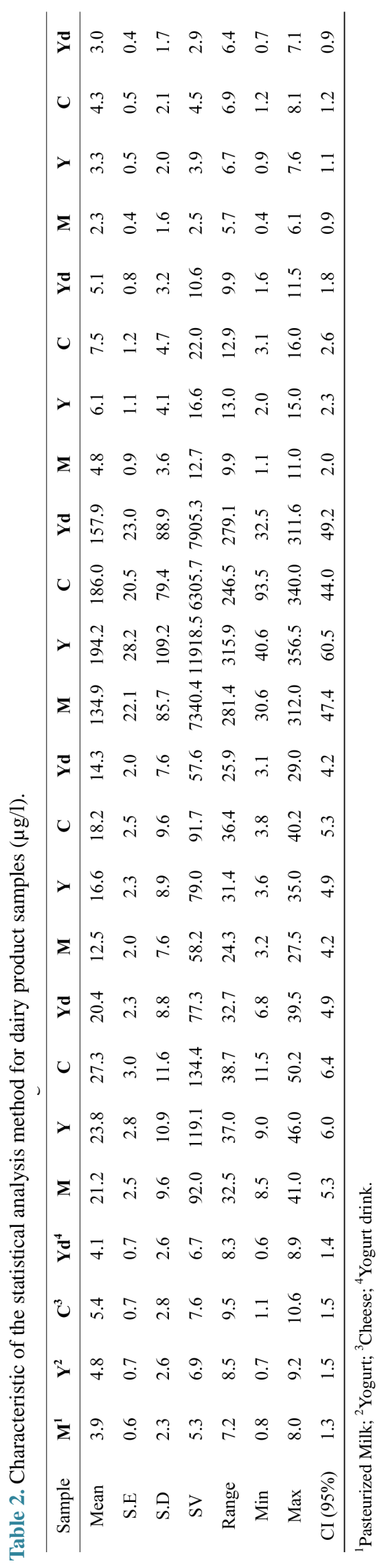


were nearly agreement with [13], that reported $\mathrm{Pb}$ and $\mathrm{Al}$ contamination in milk samples 41.8 - 58.7 and 1460 $1985 \mu \mathrm{g} \cdot \mathrm{L}^{-1}$. [14] also pointed out rate of contamination in raw milk samples of 15 different area in Iran, about $90 \%$ of the samples were less than the newly established Codex standard (20 ng/ml). Iwegbue et al. (2008) reported that all analyzed pasteurized bovine milk samples were above the one permitted by the current Brazilian legislation. In similar following studies in Romania in different country was reported average concentration of $\mathrm{Pb}$ varied from $2.73 \mu \mathrm{g} / \mathrm{kg}$ in pasteurized milk to 4.05 $\mu \mathrm{g} / \mathrm{kg}$ in hard cheese; that $\mathrm{Pb}$ were found at concentration levels less than WHO tolerated values $(25 \mu \mathrm{g} / \mathrm{kg} /$ week) [15]. In dairy products from sheep milk collected in Two Regions of Southern Italy, chromium was the highest levels in milk and lead was the highest in fresh, mature cheese and in ricotta. The compounds detected at the lowest concentrations were cadmium in milk, fresh and mature cheese $(0.05 \mu \mathrm{g} / \mathrm{g}, 0.05 \mu \mathrm{g} / \mathrm{g}$ and $0.06 \mu \mathrm{g} / \mathrm{g})$ and chromium in ricotta $(0.03 \mu \mathrm{g} / \mathrm{g})$ [12]. in milk of cattle and goats for Pakistan, concentration of lead and cadmiumranged from $42.687 \pm 0.051$ and $0.084 \pm 0.003$ $\mathrm{mg} / \mathrm{L}$, respectively and showed that the residual levels of $\mathrm{Cd}$ and $\mathrm{Pb}$ have been found higher in goat milk [16]. in Egypt, was reported that lead and cadmium contents of all the cow milk samples were 4.404 and $0.288 \mu \mathrm{g} / \mathrm{g}$, respectively [6]. In Pakistan, milk heavy metals (Cadmium, Chromium, Lead and Nickel) concentrations were found above those normally associated with suitability for human consumption [17]. Tona et al. (2013) in Nigeria, showed that all the milk and milk products samples analyzed contained residues of $\mathrm{Pb}$ and $\mathrm{Cd}$ heavy metals. heavy metal contamination in raw milk samples exceeded EU limit with percentage of $100 \%$ for lead in Lubuskie Province, Poland [18]. Also, mean levels for cadmium, lead, and mercury in the breast milk of Saudi women were $1.732 \mu \mathrm{g} / \mathrm{L}, 31.671 \mu \mathrm{g} / \mathrm{L}$, and $3.1 \mu \mathrm{g} / \mathrm{L}$, respectively [19]. Licata et al. (2004) Reported that the concentrations of $\mathrm{Pb}$ in all milk samples in Calabria, Italy were lower than EU limit (0.10 to $9.92 \mathrm{Ag} / \mathrm{kg}$ ). There are some difference between our study and others. As a reason Several factors such as exhaustion gases, industry wastes and waste waters polluted to the plants affected on heavy metal level of plant and other edible parts of feed animals and then, heavy metal is secreted to milk and subsequently entered individuals through consumption of milk and other dairy products. Also there is no information about feedstuff given to cows in sampling regions, but depending on the Planting area for agricultural products (i.e. air pollution, soil, water, etc.), dairy Production Equipment, Storage and transport containers, are important supplies of heavy metal contamination. It seems that the use of stainless steel containers, appropriate packaging and agricultural products grown in soils with low heavy metal pollution could play major role in reduction of heavy metal content in dairy product.

\section{CONCLUSION}

As regards the fact that the amount of heavy metals in most of dairy products examined was above EU limit, it is highly recommended that controlling measures should be taken promptly to reduce contamination such as implementing a food control systems (i.e. GAP and HACCP), educating dairy farmers and manufacturers. Additionally, it is suggested that subsequent studies should be conducted on heavy metals contamination in different stages of milk preparing and which factors could be involved in heavy metals contamination. The presence of heavy metals emphasizes the need for regular monitoring and a more stringent food safety management system (FSMS) in order to control the heavy metals at the lowest possible levels.

\section{REFERENCES}

[1] Iwegbue, C.M., Nwozo, S.O., Ossai, E.K. and Nwajei, G.E. (2008) Heavy metal composition of some imported canned fruit drinks in Nigeria. American Journal of Food Technology, 3, 220-223. http://dx.doi.org/10.3923/ajft.2008.220.223

[2] Rezaei, M., et al. (2013) A survey of microbial total count and prevalence of Escherichia coliin raw milk in Markazi Province, Iran. Research Opinions in Animal and Veterinary Sciences, 3, 474-477.

[3] Teimoory, H., et al. (2013) Antibacterial activity of Myrtus communis L. and Zingiber officinalerose extracts against some Gram positive pathogens. Research Opinions in Animal and Veterinary Sciences, 3, 478-481.

[4] Namihira, D., Saldivar, L., Pustilnik, N., Carreón, G.J. and Salinas, M.E. (1993) Lead in human blood and milk from nursing women living near a smelter in Mexico City. Journal of Toxicology and Environmental Health, 38, 225-232. http://dx.doi.org/10.1080/15287399309531714

[5] Isaac, C.P., Sivakumar, A. and Kumar, C.R. (2012) Lead levels in breast milk, blood plasma and intelligence quotient: A health hazard for women and infants. Bulletin of Environmental Contamination and Toxicology, 88, 145149. http://dx.doi.org/10.1007/s00128-011-0475-9

[6] Malhat, F., Hagag, M., Saber, A. and Fayz, A.E. (2012) Contamination of cows milk by heavy metal in Egypt. Bulletin of Environmental Contamination and Toxicology, 88, 611-613. http://dx.doi.org/10.1007/s00128-012-0550-x

[7] Fatima, I., Wasim, M. and Rehman, S. (2011) Dietary exposure to essential and toxic elements from fresh, pasteurised and powder milk samples from pakistan. Nucleus, 48, 315-322.

[8] Fani, A., et al. (2013) Aflatoxin Occurrence in Nuts Consumed in Arak, Iran. International Journal of Food Safety Nutrition and Public Health, 4, 91-97. 
[9] Rezaei, M., et al. (2013) Nitrite in hamburgers in Arak, Iran. Food Additives \& Contaminants: Part B, 1-4.

[10] Afridi, H.I., Kazi, T.G., Kazi, N.G., Jamali, M.K., Arain, M.B., Sirajuddin, Baig, J.A., Kandhro, G.A., Wadhwa, S.K. and Shah, A.Q. (2010) Evaluation of cadmium, lead, nickel and zinc status in biological samples of smokers and nonsmokers hypertensive patients. Journal of Human Hypertension, 24, 34-43. http://dx.doi.org/10.1038/jhh.2009.39

[11] Jalbani, N., Kazi, T.G. and Hassan, I. (2009) Determination of toxic metals in different brand of chocolates and candies, marketed in Pakistan. Pakistan Journal of Analytical \& Environmental Chemistry, 10, 48-52.

[12] Anastasio, A., Caggiano, R., Macchiato, M., Paolo, C., Ragosta, M., Paino, S. and Cortesi, M.L. (2006) Heavy metal concentrations in dairy products from sheep milk collected in two regions of southern Italy. Acta Veterinaria Scandinavica, 47, 69. http://dx.doi.org/10.1186/1751-0147-47-69

[13] Kazi, T.G., Jalbani, N., Baig, J.A., Kandhro, G.A., Afridi, H.I., Arain, M.B., Jamali, M.K. and Shah, A.Q. (2009) Assessment of toxic metals in raw and processed milk samples using electrothermal atomic absorption spectrophotometer. Food and Chemical Toxicology, 47, 21632169. http://dx.doi.org/10.1016/j.fct.2009.05.035

[14] Tajkarimi, M., Ahmadi Faghih, M., Poursoltani, H., Salah Nejad, A., Motallebi, A.A. and Mahdavi, H. (2008) Lead residue levels in raw milk from different regions of Iran. Food Control, 19, 495-498. http://dx.doi.org/10.1016/j.foodcont.2007.05.015

[15] Grădinaru, A.-C. Popescu, O. and Solcan, G. (2011) Variation analysis of heavy metal residues in milk and their incidence in milk products from Moldavia, Romania. Environmental Engineering and Management Journal, 10, 1445-1450.

[16] Javed, I., I. Jan, Muhammad, F., Zia-ur-Rahman, Zargham Khan, M., Aslam, B. and Sultan, J.I. (2009) Heavy metal residues in the milk of cattle and goats during winter season. Bulletin of Environmental Contamination and Toxicology, 82, 616-620. http://dx.doi.org/10.1007/s00128-009-9675-y

[17] Farid, S. and Baloch, M.K. (2012) Heavy metal ions in milk samples collected from animals feed with city effluent irrigated fodder. Greener Journal of Physical Sciences, 2, 010-017.

[18] Pilarczyk, R., Wójcik, J., Czerniak, P., Sablik, P., Pilarczyk, B. and Tomza-Marciniak, A. (2013) Concentrations of toxic heavy metals and trace elements in raw milk of Simmental and Holstein-Friesian cows from organic farm. Environmental Monitoring and Assessment, 185, 83838392. http://dx.doi.org/10.1007/s10661-013-3180-9

[19] Al-Saleh, I., Shinwari, N. and Mashhour, A. (2003) Heavy metal concentrations in the breast milk of Saudi women. Biological Trace Element Research, 96, 21-37. http://dx.doi.org/10.1385/BTER:96:1-3:21. 